\title{
Roposals FOR A PRACTICAL SYSTEM OF SIGNIFICANCE EVALUATION IN ARCHAEOLOGICAL HERITAGE MANAGEMENT
}

\author{
Jos Deeben, Bert J. Groenewoudt and Daan P. Hallewas
}

Dutch State Archaeological Service, Amersfoort Willem J.H. Willems University ofLeiden

\begin{abstract}
Signifirance evaluation plays .1 central role ID an haeological herituge management In this pilnu, a pri utiral approai $\mathrm{h} r$. present et I based on expei ieni es and recent discussions in the Netherlinds, A restricted numbes ol values (perreption, physical quality and intrinsic quality) are opetationalized as criteria in order In evaluate archaeological phenomena. In this manner .1 more transpirent framework is created to help determine it, 1 monument is worth preserving In Ihr process of selection monuments worth preserving are scrutinized from the viewpoints ot policy consideritions and priorities in archaeological heritage management in order to select monuments deserving of sustained preservation. Ihr form of this svstem ol signitic ance evaluation is such that $\mathrm{U}$ r an be used bv all government levels. that the process is understandable tor non archaeologists, and thit its results remain relevant trom a research perspective.
\end{abstract}

Keywords: archaeological heritage management, Netherlands. selection, valuation

INTRODUCTION

The 1970s and even more markedly, the earl 1980s witnessed major shifts in attitude towirds the archaeological heritige, in the Netherlands as well as elsewhere in Europe. On the one hand, arrhaeologiral monuments, in the sense ol both movable and fixed pirts of the cultural heritage, were no longer seen primarily as objects of studv, bul as cultural resources to be ot use and benefit in the present and the future (I ipe 1984) On the other, a clear trend emerged towards replacing the notion of 'care and protection of monuments' bv a new approach - the management of these archaeological lesouives. It was soon realized that this could not be done by

Luropean Tounal of Archaeology Vol. 2(2): 177-199 Copyright ic 1999 Sage Publications (I ondon, Thousand Oaks, C,A and New Delhi) and the luropean foiodttion of Archaeologists [146]-9571(1999: : -199;008989] 
viewing monuments in isolation. This must he done in three contexts: (1) the natural and the man-made landscape, at a regional scale (Groenewoudt and Bloemers 1997); (2) political developments such as the impetus of the green debate (Macinnes and Wickham-Jones 1992); and (3) the ongoing process of land-use planning (Bloemers 1997).

The management of archaeological resources can be described as a cyclical process (Fig. 1), based on documentation and registration, followed by the stages of inventory-taking, significance assessment, selection, protection/conservation or excavation, and finally interpretation/synthesis and communication, which will provide the necessary feedback (Willems 1997:3). Discussions about the practical operations of the cycle have recently flared up in the wake of the implementation of the Malta Convention (Council ot Europe 1992). The debate centering on the themes ot valuation and selection of archaeological monuments in particular has onlv recently started in the Netherlands (Groenewoudt 1994, '( iroenewoudt and Bloomers 1997). In English-speaking countries, this debate has been carried on tot much longer (e.g. Briuer and Mathers 1996; Darvill et al. 1987; Darvill et al. 1995; Startin 1993). In the Netherlands, valuation and selection are part of the broader discussion about the reorganization of the system of archaeological heritage management and the tasks to be assigned to those participating in it, a debate that currentlv is a live topic in many European countries.' The purpose of this debate $\mathrm{m}$ the Netherlands is to achieve a more effective division of labour, which should take the form ot complementary collaboration between different levels of government and a well-defined role for academic research and private enterprise.

Valuation and selection are on the agenda because, under new legislation based on 'Malta' principles, authorities will oblige developers to assess the impact of their plans on the archaeological heritage and to fund the necessary archaeological research. This presumably - will be done on the basis ot a valuation, made by an authorized individual or agency, followed by a selection proposal on which the national, regional or local authorities can base theil decision In select monuments. This decision will determine whether an archaeological monument is.. lassified as significant and, if so, whether it can be preserved or whether an excavation should take place and indeed what aspect should be investigated. The initiator is obliged to bear the cost of this research: hence these are government decisions against which appeals may be lodged. This legal aspect, and also the aspect ol quality control in archaeological heritage management itself, mean that the process of decision-making should he followed through with utmost care. Since not only the national government will strive for the conservation of monuments, there is a need for consensus of authorities at all levels about the system of valuation and selection to be adopted; therefore the system must of course be capable of implementation on all levels. Further, it is important that criteria be identified and used in such a way that it is clear also to the non-archaeologist what the decisions are based upon. 


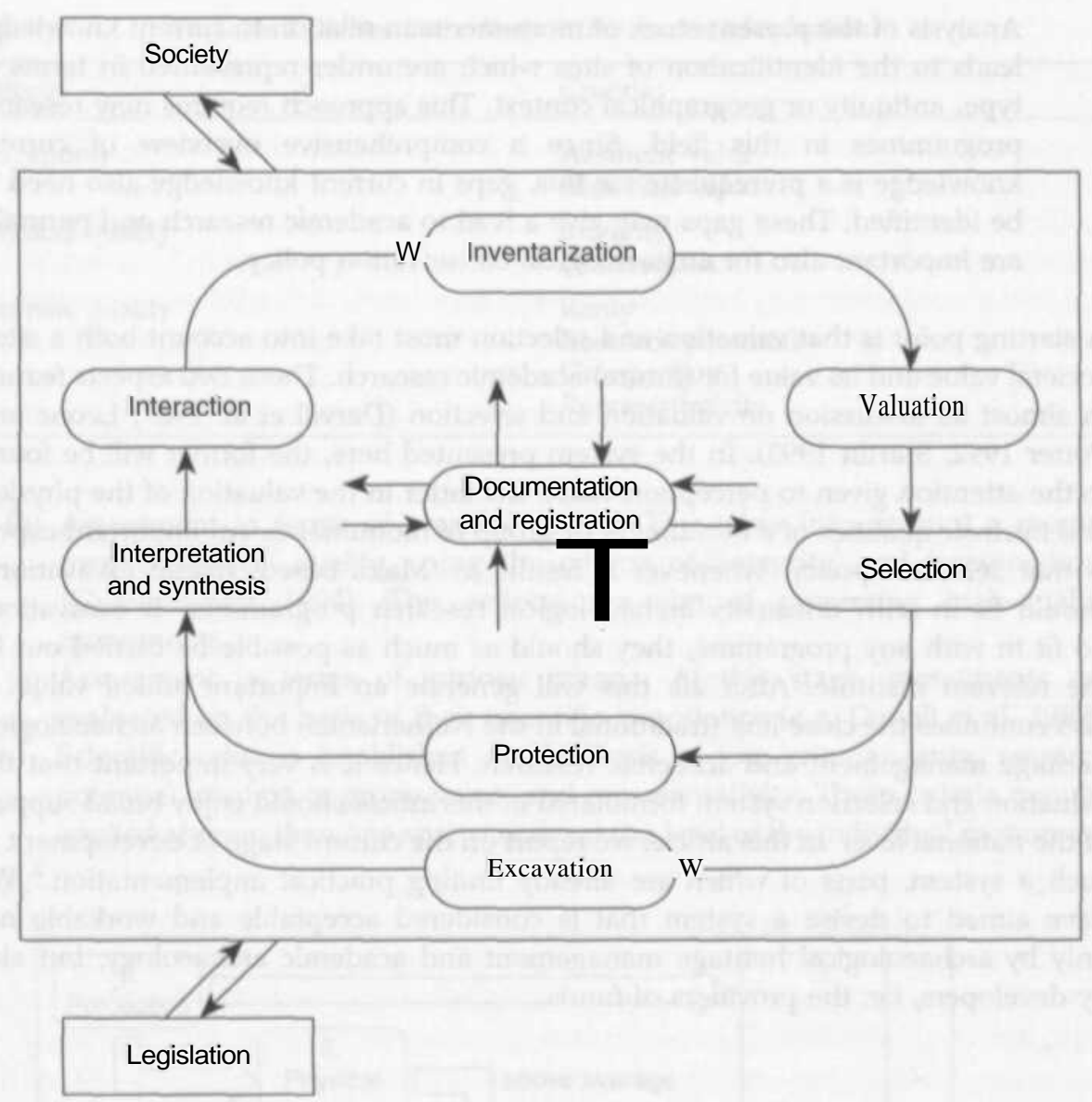

Figure 1 The cyclical process of an haeological heritage management.

The context in which valuation and selection take place takes two principal forms:

(a) Valuation and selection in land use planning.

Dealing with archaeological values in planning procedures is already taking fairly definite shape in formalized prospection protocols. In this context, valuation and selection are aimed at both protection and research $O n$ the one hand, planning procedures may allow the creation ot conditions necessary for sustained conservation, on the othes hand, some archaeological phenomena that are considered important will have to be investigated, because otherwise they will be lost.

(b) Valuation and selection with a view to preserving a stock of monuments that to the best of our knowledge is lepresentative of the soil archive. 
Analysis of the present stock of monuments in relation to current knowledge leads to the identification of sites which are undel-represented $\mathrm{m}$ terms of type, antiquity or geographical context. This approar $h$ requires new resear $h$ programmes in this field. Since a comprehensive overview of current knowledge is a prerequisite tor this, gaps in current knowledge also need to he identified. These gaps may give a lead to academic researc $h$ and naturallv are important also for archaeological conservation policy.

A starting point is that valuation and selection must take into account both a site's societal value and its value for (future) academic research. These two aspects teature in almost all discussion on valuation and selection (Darvill et al 1987: Leone and Potter 1992; Startin 1993). In the system presented here, the former will he found in the attention given to perception value; the latter in the valuation of the physical and intrinsic qualities of a monument or group of monuments. An important aspect is that selection policy, whenever it results in 'Malta based' rescue excavations, should fit in with university archaeological research programmes. If excavations do fit in with any programme, they should as much as possible he carried out by the relevant institute. After all, this will generate an important added value. It also continues the close link (traditional in the Netherlands) between arrhaeologiral heritage management and academic research. Hence it is very important that the valuation and selection system formulated in this article should enjoy broad support at the national level. In this article, we report on the current stage of development of such a system, parts of which are alreadv finding practical implementation. We have aimed to devise a system that is considered acceptable and workable not only by archaeological heritage management and academic archaeology, but also by developers, l'e the providers of funds.

\section{THE PROCESS OF VALUATION AND SELECTION}

Valuation and selection represent different stages in the process of decision-making. This process comprises several different steps In valuation, three general values are distinguished, which may be made more specific as a series of criteria (Table 1). The general values correspond to steps to be followed in the process of valuation (Fig. 2).

(a) Assessment of a monument's perception. At this stage, monuments are evaluated in terms of i rifelia that reflect then perception value. This can be subdivided into 'aesthetic value' and 'historical value'. Perception value can serve as a tool for preserving especially that which is visible. It is about appreciation of the archaeological heritage from the public's point of view (Darvill 1995). 
Table I Values and criteria in the process of valuation

\begin{tabular}{ll}
\hline Values: & Criteria: \\
\hline Per eption & Aesthetic value \\
& I listorical value \\
Phvsical quality & Integrity \\
& Preservation \\
Intrinsic quality & Rarity \\
& Research potential \\
& I iroup value \\
& Representativity
\end{tabular}

(b) Assessment in terms of physical criteria. This takes into account a monument's physical quality, using the criteria of 'integrity' and 'preservation' (( iroenewoudt 1994). This reflects the aim ot preserving high-quality monuments.

(c) Assessment in terms of intrinsic criteria At this: stage, monuments are evaluated on the basis of theil scientific importance (e g. Darvill et al. 1987) Scientific value is established on the basis ot fou ciitena: rarity, research potential, context or group value, and representativity. These criteria mav be applied at more than one spatial scale:at the level ot the individual monument

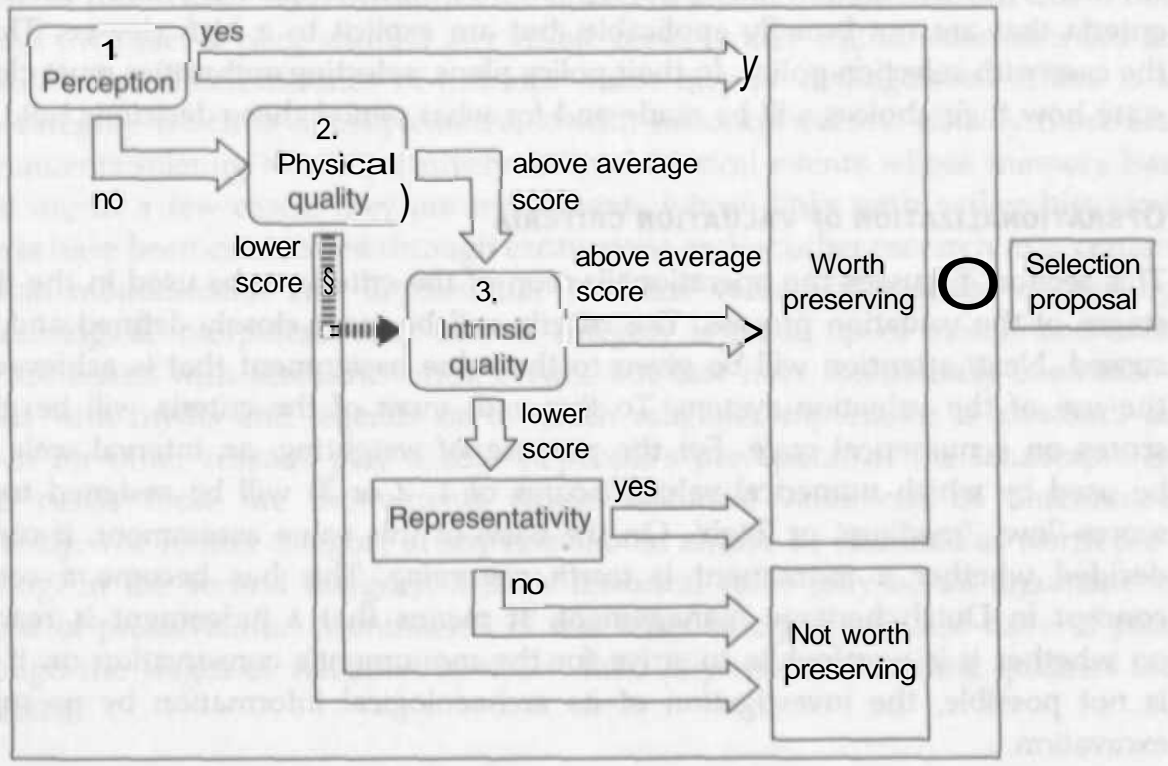

Figure 2 The stages in the process of valuation. 
and that of micro-regions containing several monuments (Moratto and Kelly 1978:2). At this stage, the aim of preserving intrinsic quality is furthersubstantiated, and opportunities are created for realizing the objective of retaining a representative stock of monuments (e.g. Darvill et al. 1987; Reed 1987).

( )n the basis of data collected during the valuation process, a selection proposal is drawn up for those monuments that are deemed worth preserving. This step in the process should be carried out by the government itself, through the archaeological service of the authority concerned. These recommendations are tested against the selection policy laid down by that authority, which records the points to be considered in making choices and the priorities to be observed in selection (( iroenewoudt and Bloemers 1997). At this point, consideration may be given to the option of preserving larger geographical units, while at the same time observing planning procedures and working in collaboration with government authorities. Besides, this is where the struggle takes place for maximum results. A crucial point in the present ideas about government in the Netherlands is that everv level of government should in principle be tree to pursue its own policies and hence to make its own selection choices.

At these stages of the procedure, we are dealing with three different types ol criterion. In the first place, there are broadly applicable criteria that can be verv precisely specified. This is the case with the assessment of physical quality. In the second place, there are broadly applicable criteria that require a description; thev leave a wider margin for interpretation on the basis of expert judgement. This is the case with the assessment of perception and intrinsic quality Finally, there are criteria that are not broadly applicable, but are explicit to a high degree. This is the case with selection policy. In their policy plans, selecting authorities must clearlv state how their choices will be made and for what period these decisions hold.

\section{OPERATIONALIZATION OF VALUATION CRITERIA}

This section discusses the operationalization of the criteria to be used in the three stages of the valuation process. The criteria will be more closely defined and discusse $\bullet$. Next, attention will be given to the value assignment that is achieved by the use of the valuation system. To this end, most of the criteria will be given scores on a numerical scale. For the purpose of weighting, an interval scale will be used by which numerical values (scores of 1,2 or 3 ) will be assigned to the scores 'low', 'medium' or 'high'. On the basis of this value assessment, it can be decided whether a monument is worth preserving. This has become a central concept in Dutch heritage management. It means that a judgement is reached on whether it is worthwhile to strive for the monument's conservation or, if this is not possible, the investigation of its archaeological information by means of excavation. 
Assessment of perception value

The perception value of an archaeological monument can be measured by two criteria: 'aesthetir value' and 'histoiical value'. In both cases, these mainly relate to visible monuments. 'Aesthetic value' refers to the value ot ar haeological monuments as parl of the landscape, which can generally be translated as visibilitv. ${ }^{3}$ This criterion centres on the external appearance of the monument, in the sense of its condition shape and texture in relation to its surroundings. Aspects to be considered include the monument's visibility as a landmark, its. links with other (visible) mon uments 01 geographical teatures and its setting in the landscape, in briet the degree to which a monument mav please bv its external characteristics.

The concept ot aesthetir value is barely ever used in archaeological practice. Operationalizing aesthetic value as 'visibility' produces a workable criterion. Visible monuments constitute a powerful remindel ot the past and therefore should be preserved as much as possible even if their scientific value in certain cases is slight. The Dutch landscape is intensivelv cultivated; as a result of building and reclamation there is a relative scarcity of field monuments, both in the form ot 'positive' (above-ground) and "negative' (dug out) relief features. Examples are dwelling mounds (terpen), megalithic tombs (hunebedden), barrows, mottes, and moats. Visibility is a lelative notion. The chararteristics both of the monument itself and of its immediate surroundings decide whether a monument may be classified as 'worth preserving' on the grounds ot visibility.

The historical value ot an archaeological monument relates to the memories of the pasi that it evokes Some monuments represent a living memorv ot the past (Schuvf 1995). In most cases, such memories are linked to a field monument, but this is not always the case. A plare withoul any visible remains mav still function as a lieu de mémoire. Two different kinds of historical value may be distinguished. There is a rare category which is directlv connected with historical events. Usuallv these are monuments relating to comparatively recent histoiical events whose- memory has lived on; in a tew eases, they are monuments whose links with earlies histoiical events have been established through excavations and/or othel research (e g c ertain Roman monuments). This implies that historical value mav also be created bv an haeological interpretation. A second category is made up of monuments that an- not linked with actual historical events, but that have traditionally been assoelated with mvths and legends or to which religious importance is attached, or which for othei reasons play a role in people's perception ot the landscape. In both cases, these- are monuments whose- historical value- can he determined explicitly. The tormel category at anv late should always be-classified as worth preserving. In the second category, a site's historical value may he an argument in tavou of preservation. ${ }^{4}$ Monuments ot this latter category will also have to pass through the stages ot valuation in which their physical and intrinsic qualities ate assessed. 
Together with other, non archaeological landscape features, archaeological monuments may contribute significantly to the aesthetic, educational and recreational quality of an area. Monuments with a high perception value are pre-eminentlv suitable to generate popular support for the protection of arrhaeological monuments in general.

\section{Assessment on the basis of physical criteria}

On the basis of physical criteria, a judgement is made as to whether a non visible monument is worth preserving in principle. The valuation of such monuments involves the assessment system developed by (iroenewoudt (1994). In this system, the concepts of 'integrity' and 'preservation' play a crucial role. Already a tew years' experience has been gained with this method tor assessing physical quality. In practice, it is found to work well, in the sense that experts regard the results as relevant and that its application by different experts produces identical or at any rate very similar results. I Ience the method is considered .1 reliable one.

Physical quality is the degree to which archaeological remains are still intact and in their original position. $T_{i} \ldots . .$. this value, a distinction is made between the criteria of integrity (the degree to which disturbance has taken place) and preservation (the degtee to which the archaeological materials have survived). By means of site-oriented investigation in the field, evidence may be obtained about the physical condition of a monument, which will allow an assessment that is reliable as well as objective - in the sense that comparable results are reached by different investigators.

Fo1 this purpose, several methods, techniques and parameters have been developed (see Appendix). Some of these are broadly applicable; in other cases, their applicability depends on local conditions or the physical charar teristis of the type of monument to be .... . d . Two categories of parameter can be distinguished. ( )ne category offers an insight into the quality determining conditions onlv (e.g. soil structure, hydrology). The other category provides concrete intormation aboul the presence, quantity and quality of the sour es, of archaeological evidence as well as the dimensions of the site. The assessment of the physical quality of a monument is underpinned by a description of the parameters and observations on which this valuation is based. This makes the assessment verifiable.

\section{Assessment on the basis of intrinsic criteria}

After the assessment of physical quality, it is clear which archaeological monuments are $\mathrm{m}$ principle 'worth preserving'. Subsequently, these monuments are evaluated on the basis of their intrinsic quality. The national government at this stage checks whether the sites deemed worth preserving are of national on international significance. This section discusses the ciperationalization of these criteria at the 
national level to produce a set of guidelines. The nature of each criterion is such that ther are easilv operationalized by lower levels ot government for implementation at the regional or local level. The criteria are as follows:

(a) Rarity

(b) Research potential

(c) Group value (archaeological and geographical context)

A special role is reserved tor the fourth criterion, which cornes into play only if there is, 1 possibility of in situ conservation of the site

(d) Representativity

'Rarity' is defined as the degree to which a certain type of monument is (or has become) scarce in . 1 period 01 region Raritv therefore is a relative notion The assessment of raritv rests on current insights into the content and composition ot the soil archive. To determine rarity value, we need insight into the extent and varietv of the archaeological heritage ol the Netherlands, how much ot it is left and the condition it is in Such insight requires intormation that currently is available only to a limited extent. This has two implications. First archaeological heritage management at the national level must, in consultation with universitv departments and archaeological services at lower governmental levels, formulate a research programme aimed at acquiring specific knowledge in this area (see later). As tat as the condition of the heritage is concerned, a survey comparable to the recentlv published MARS (Monuments at Risk Survev) project in England (Darvill and Fulton 1998), could provide the necessarv intor illation.

The second implication is that we shall have to work on the basis ot existing information which, as the earlier mentioned programme is carried out, will be progressively refined and expanded with more specific data. Dutch archaeology still does not possess a workable inventory of the state ot archaeological knowledge. At present, there is onlv a very general, initial survev ( iroenewoudt and Bloemers 1997: Fig. 12) which, in its organization, is broadly comparable to the English model (C.) livier 1996). It is important to develop a detailed inventory ot knowledge and gaps in our knowledge, to be compiled tor ear $h$ ot the various archaeologirally' legions that make up the countrv's 'archaeo legions' (Fig .3: C iroenewoudt 1994; Fig h). This is to be done in the coming vears.

The assessment ot rarity is based on a score lor each type of monument pel archaeo legion and pel pel iod. Rarity is, assessed as 'low' (score 1), it there are a large number ot similar, coeval monuments in the legion which are in a similar of even better slate ol preselvation. This can be determined either on the basis of available data (e g an inventorr) 01 on the grounds ot expectation, provided this is based on a recent and specific predictive map Raritv is judged to be 'high' (score 3) if the monument is unique or if verv few similai monuments survive in the region. In all othel cases, a 'medium' scoie will ensue ()ften monuments will scoie 'medium' lather than 'low' simply because insutficient evidence is available, particularly 

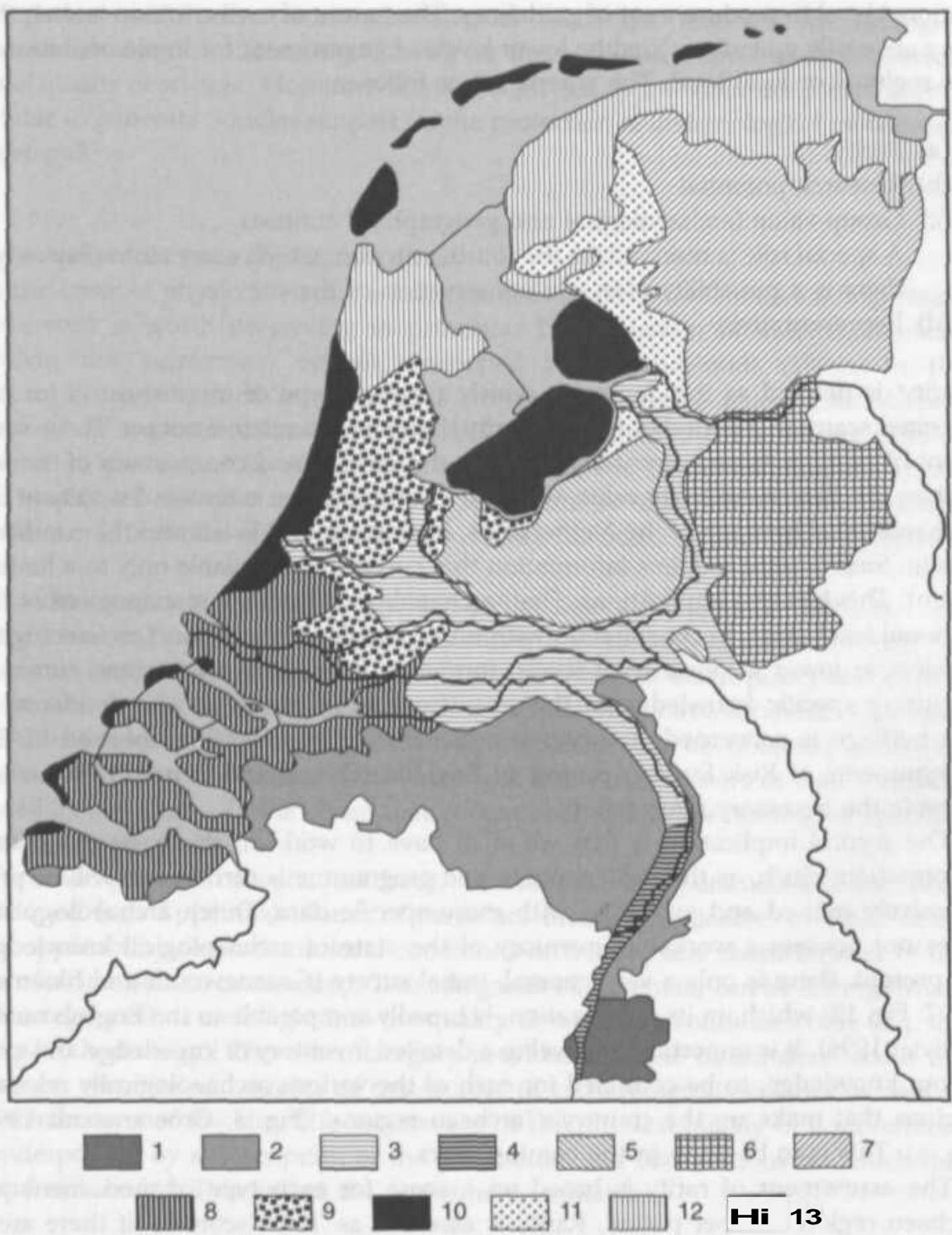

Figure 3 Archaeologicallyrelevant regions within the Netherlands Ian haeo regions). Legend:

1 Ihr Hills of Zuid Limburg:

2 the Southern Sandy Area;

3 the Central River Area;

4 the Meuse Valley;

5 the Central Sandy Area:

6 the Eastern Sandy Area,

7 the Northern Sandy Area;
8 the Southwestern Marine Area;

9 the Western Low lyingPeal Moors; $H I$ the ZuiderzeiArea;

11 the Northern Low lying I'eat Moors;

12 the Northern Marine Area;

13 the Dune Area. 
monuments other than settlements: For instance, cemeteries (olde1 than sub recent) will therefore onlv sporadically score 1 : thev are difficult to find and even when many more examples are thought to exist, it is usually difficult to assess their integrity and preservation.

'Research potential' is the signiticance of ,1 monument as a source of knowledge about the past Research potential reflects the amount ot new knowledge about the past that (excavation ot) the monument might generate. This mav equally be the closing ot gaps in such knowledge 01 the opportunity to formulate alternative interpretations ol the past (pluriform knowledge acquisition). The results ot anv investigation are closelv related to its questions and objectives: to make alternative interpretations possible, new excavations are usuallv needed to gather relevant data. Hence the question is not onlv whether new evidence is expected to fill lacunae, but also whether it is expected to be relevant to ciment research needs. Further, it should be noted that research potential is also determined by a monument's 'group value' The research potential ol a complex of monuments in an archaeologically and geographically coherent ensemble usuallv exceeds the sum ot its componeni parts.

The research-potential score of a monument is based on an analvsis ot lacunae in knowledge and current research objectives. In the first instance, it is decided bv the current state ol leseaich relating to similar monuments ot the same period in the same archaeo-region. Hut, as with rarity value, onlv an initial, global inventorv is available for this purpose and the same steps are necessary here to achieve improvement. Different types of knowledge lacunae mav be distinguished, which may or may not occur in combination:

(a) geographical knowledge lacunae areas about which comparatively little evidence is available;

(b) chronological knowledge lacunae: periods about which we are still comparatively poorly informed:

(c) intrinsic or thematic knowledge lacunae: these relate to various aspects (themes and processes) of the (pre)history of the Netherlands.

Keseaich potential is generally 'high' if the rarity value scores highly, but the other semes may differ even about common types ot monument there may be knowledge lacunae, whereas a monument that scoies 'medium' on raritv value may belong to a category about which much is known. A specific tactol determining reseaich potential is the relevance ot the anticipated intormation vield to current research objectives. This is derived from the current research programmes. ol the archaeological bodies operating nationwide: the universitv departments and the state service $(\mathrm{KOM})$. It excavation ot a specitic monument tits into one ot these programmes, its leseaich potential is always high (score 3 ) This variable must be backed by $a$ periodically reviewed, explicit inventorv ol running research piogiammes which are given nationwide publicity. This does not mean that the option of preserving 
the monument is abandoned: a site's relevance to current research does play a part, even if at a later stage the option arises to preserve the monument.

By 'group value', we mean the extra value that a monument gains through still having an archaeological and/or geographical context. 'Archaeological context' refers to the preseni $r$ and the research potential of nearby sources of archaeological evidence. This may be a synchronie context - in the close vicinitv there are further monuments of the same archaeological period, allowing intes site analvsis of , I diachronic context - there are monuments from various periods, allowing an evolution (a historical process) to he studied

'Geographical context' is the degree to which the original geographical context is still present and/or recognizable; the presence ol organi sediments $\mathrm{m}$ a monument's vicinity is an important consideration. Such elements contribute significantly to the possibilities for research of past landscapes and land use.

A monument's group value is determined on the basis of its 'close vicinity'. Thus it is not the archaeo-region as a whole that counts, but the micro region (also referred to as an 'archaeological-geographical ensemble' or 'community area' (Neustupny 1991), which is usually the basic geographical unit in archaeological research. This is defined $\mathrm{M}$ an area in which it is expected that there are functional or socioeconomic links between the archaeological phenomena and the surrounding landscape, viz. links relating to the functioning of a community in a particular period or to the area's occupation through the centuries. The extent ot such a microregion will depend on the research objectives and the period(s) under study.

A monument's group value is established on the basis ot both archaeological and geographical contexts. Usually, the starting point is a (field) survev or inventorv (( iroenewoudt and Bloemers 1997:136-7), in combination with additional data on the surroundings, e.g taken from predictive maps (I)eehen et al. 1997). This supplies the basis lor evaluating the geographical context and may furnish additional details tor use in ; the archaeological context. If neithes context has survived to any significant extent, group value is recorded as 'low', it one ol eithes is not ot is no longer present or is seriously disturbed, the score is 'medium' and it both are extant to a significant extent, group value will be 'high'.

'Representativity' is the degree to which a certain type ot monument is typical of a period or an area (chronological or chorological representativity) . In the intrinsicvalue tent, an important part is also played by the criterion ol representativitv. However, in contrast to rarity, research potential and group value, representativity is relevant only if eventual conservation ot the monument is an option. This is inherent in the definition and operationalization ot the concept. After all, the aim is to safeguard representative samples that, from an (inter)national point of view, are characteristic of (parts of) the Netherlands. The typicality of a monument may be determined both quantitatively and qualitatively. In its qualitative sense, the concept ot typicality may relate to specific views about the interprétahon of material culture, e. g. V. ( iordon ( hilde's definition of 'culture'. In this sense, also rare or even unique monuments may be representative In our proposed svstem 
ut valuation, such monuments are alreadv given special consideration through their raritv value Hence we are here dealing exclusivelv with monuments of wellrepresented 'types' The greates the number of known, similar monuments from the same period and the same part ot the countrv (archaeo legion), the more 'representative' individual monuments will be; it is on this basis that their typicality will be assessed Such monuments will generally not be considered for selection on the grounds of the first three intrinsic value criteria. This would produce a result at odds with an important principle of archaeological heritage management: the sateguarding of a representative sample tol the future Aftei thei intrinsic value has been assessed in terms of the tirst three criteria monuments that in principle could be preserved tor the future should therefore be assessed bv the criterion of representativity. Protection on Ihe grounds ol (among other things) representativity presupposes the existence of a government policy that is serious about their conservation. Where this indeed is the case, assessment of a monument's representativity (on the basis ot the inventorv mentioned earlier per aichaeo region) may take plar $f$.

'Representative' monuments should preferably have a high group value. In principle, archaeological geographical ensembles scoring highly on synchronic and diachronic context will include many 'typical' archaeological monuments. Bv definition, such monuments will score 'low' on rarits and 'medium' on research potential. This is generally the rase with sites ot comparatively slight antiauitv. The number to be selected fol conservation.strongly depends on practical and policy considerations. In terms ol intrinsic quality, the international perspective is ot special importance tor deciding the size ot the sample. II the type ol archaeological monument is tank common internationally, the number to be preserved at the national level mav be more modest

\section{Weighting}

The weighting ot the various criteria has already been mentioned as well as the wavs in which criteria after I each other This section presents a briet description ol the weighting process (Table 2).

Table : The weighting of values and criteria (NA = not applicable).

\begin{tabular}{lllll}
\hline Values & Criteria & \multicolumn{3}{c}{ Scores } \\
\cline { 3 - 5 } & & high & medium low \\
\hline Perception & Aesthetic value & NA & & \\
& I Iistorical value & NA & 2 & 1 \\
Phvsical quality & Integrity & 3 & 2 & $1(2)$ \\
Intrinsir quality & Preservation & 3 & 2 & 1 \\
& Rarity & 3 & 2 & 1 \\
& Researh potential & 1 & 2 & 1 \\
& Group value & NA & & \\
\hline
\end{tabular}


In the first place, checks are made whether monuments may be classified as worth preserving on the grounds of perception value - because of theil aesthetic or historical value. In the system as described here, it has been decided that a positive judgement on these parameters must always lead to positive selection. ()| course it is also possible to attach a numerical score to perception value, which counts as part of the total score. Monuments with a high perception value will then only be classified as worth preserving if their scores on the other criteria too are sufficiently high.

The remaining monuments will then be assessed in terms of their physical quality. A monument's physical quality will generally put it in the 'worth preserving' category if the criteria of integrity and preservation togethes score above average (five or six points). ${ }^{5}$

Monuments that on the grounds of their physical quality have been classed as in principle worth preserving are then evaluated $m$ terms of their intrinsic quality. With an above-average $s<$ ore ot seven points or more on the intrinsic criteria, a monument will be classified as worth preserving For monuments with a lower score. checks are made to decide whether the criterion of representativity is applicable. If so, a proposal will be made to conserve it as a sample of a category worth preserving. All remaining monuments will be classified as 'not worth preserving'.

There are, of course, alternatives to the step-by-step weighting process as described earlier As already mentioned, perception value may be treated differentlv and the weighting need nol necessarilv be done step by step These and other alternatives need to be tested in practice, in order to gam experience and to be able to compare and evaluate the results.

The monuments classed as 'worth preserving' will be subjected to selection. Earlier, it was noted that there is no point in assessing some criteria if, in practice, sustained preservation is not an attainable option. In the case of other criteria, valuation is in part determined by current lesearch requirements. Hence valuation cannot be separated from its social and academic context.

\section{SELECTION}

Selection, which follows valuation, revolves around two things: policy considerations and choices in the form of priorities. Fach level of government will make its own policy decisions. After all, what may not be of particular interest on a national scale may be considered of great importance locally. Moreover, local government may wish to place a particular emphasis with a view to local or regional identity, or for othe1 reasons, which do not have a resonance at the national level. Since these choices may have scientific as well as legal and economi repercussions, the starting points and priorities on which they are based need to be laid down in policy documents. Priorities are always formulated with the primary objective of conserving archaeological monuments, by means of (at the national level) statutory 
protertion and other instruments, such as planning legislation. In the implementation ot policy in concrete selection decisions, a wide range ot more specific policy considerations may come into play. I lere a tew will be mentioned which are important at the national level.

An important consideration in the implementation ot conservation policy is that of public support. Public interest in archaeology is directly related to the social basis tot archaeological heritage management and hence ot" vital importance. A recent studv among the Dutch population made it manifestlv clear that such interest focuses mainly on matters that appeal to the imagination: Romans, megalithic tombs, castles and the like, On the oilier hand, liiere often is broad support at the local level tor specific monuments that are not of special national importance Regional and local authorities would do well to exploit such points ot contact in the implementation of their policies, so as to strengthen public support tor their overall conservation policies. Here it is also important to note that, in contrast to other culture historical disciplines, archaeology influences the public's perception and opinion not so much through conservation as through excavations. A good understanding and collaboration between levels ot government and other parties involved in environmental planning is an absolute prerequisite tor the proper protection of the interests of archaeological heritage management. Given that archaeological interests often clash with other societal and economic interests, conflicts in this area must not be dodged In such situations, if Is important not to lose sight of the long term perspective It is essential that one's chosen position is properly explained, both to those directlv involved and to the broader public.

Making choices involves not onlv setting priorities but also deciding on pos teriorities. The objective ol preserving monuments marked as representative presupposes a level of government that will take action to ensure such preservation How governments wish to deal with representative monuments must be laid down in national, regional or local policy plans. Yet it is highly likely that such plans mark as posteriorities categories ot monuments that on the grounds of representativity might be selected tor conservation: tol example, the still verv numerous post-medieval monuments (post dating AD 1500). Therefore, it is important to exploit opportunities wherever thev arise This may be possible especially in places where an area oriented archaeologir al policy is to be' implemented. This facilitates preservation of monuments in larger, integrated areas. In such a situation typical monuments, which normally would not be considered for selection, may share in the benefits.

Furthermore, archaeological heritage management will derive great benefit from well thought out complementary collaboration between government levels, in which policy choices are harmonized to produce congruent priorities. A good example ol complementary collaboration in the Netherlands is the attention that manv local authorities give to the soil archive in town centres, fol which in future a more opportunity creating and supportive national policy should be implemented. 
It has already been mentioned that the degree of threat isian essential consideration in the setting of priorities with respect to conservation and excavation. It is logical that (acutely) threatened monuments and ensembles are often given priority in policy implementation. Such deployment for preserving evidence bv means of excavation makes sense only if enough time and means are available to document properly those aspects of the monument to which it owes its status as 'worth preserving'. If preserving the actual monument is still possible, the potential yield of doing so is the crucial point. The protection of monuments on the basis of the Dutch Monuments Act is a labour intensive matter, while statutorv protection in itself otters insufficient guarantee for sustained conservation. Monuments worth preserving should only be considered for statutorv protection it it is possible to create such preconditions that sustained conservation is ensured. If that is not the case, then excavation is the preferred option ( )ften sites that ate considered fol e onservation lie in rural areas where conservation ot the monument requires periodical management intervention or a permanent, appropriate, archaeology friendly for $\mathrm{m}$ of land use. Such efforts are effective only if the long-term prospects tor conservation are favourable. That is to sav, there must be certainty about both the goodwill of those concerned and the availability of the necessary means. In the case ot important monuments, acquisition by the government is, ot course, alwavs preferable In contrast to many othes I uropean countries, however, there are hardlv any opportunities for this $\mathrm{m}$ the Netherlands. Just now and then, in the margin of large re-allotment schemes or nature development projects, is it possible for sites of major archaeological value to be brought under government ownership. An excellent way to achieve sustained , onservalion is by aiming for conservation of larger, integrated areas (cultural landscapes). This will allow the traces of an area's occupation history to survive within their context. A good wav to attain this objective is to develop an area oriented culture-historical policy, in collaboration with the other culture-historical disciplines and the levels of government concerned (see e.g. Lüning 1997). Monuments worth preserving in principle always merit the investment in management measures needed for their sustained conservation. Yet situations will arise when such measures, though possible, are extremelv costlv. Obviously, the cost in SIK h cases must be weighed against the benefit. It this equation has a negative outcome, an excavation is to be preferred Protection of a monument of a certain type can best he undertaken therefore where it incurs the least cost. When such cases arise in the inservalion of monuments seler led on the basis of representativity, which howevei are still suffir ientlv numerous, even replacement by other monuments of equal value could be considered.

In the valuation process as proposed here current academic research priorities play an important role $m$ the assessment of research potential. 1 lowever, supporting heritage research is important as well, the purpose of which is to piovide improved instruments for archaeological heritage management. Theieloie, in deciding which selected monuments should be excavated, a tactol to be consideied is whether excavation might, on the one hand, contribute significantly to improving methods 
and techniques used in archaeological fieldwork (both prospection and excavation), and, on the other, refine methods for predicting arrhaeological values. The development of methods and techniques mav also require the formulation of specific research programmes. Such programmes will naturally aftect the assessment of the research potential of monuments.

\section{THE INSTRUMENTS}

An effective process of valuation and selection will depend upon a number of instruments 01 trames ol reference all of which have been touched upon at various points in this article. Here, these will be brieflv res apitulated. In fact, valuation and selection can be viewed as parl ol an integrated svstem of quality control, in which not onk archaeological procedures, but also organizations and individuals should meet certain standards In the Netherlands, new legislation is currently being prepared in which elements of quality control play a part, because some aspects ol this lequne a statutorv basis

In the interests of a process of selection authorities should formulate, in advance. their policies regarding the conservation and investigation ot archaeological monuments and the priorities set in this held. This is important at the national level but, at the regional and local levels too, policy plans should provide such information. A national registej of all finds and sites and ot monuments enjoying anv form of protection is essential In the Netherlands, these data are recorded digitally in the central database ot Aldus, which can also be consulted and supplied with fresh data from der entralized terminals (Roorda and Wiemer 1992a: 1992b: Zoetbrood el al. 1997)

At the national level, the tirst generation ol an 'Indicative Map ol Archaeological Values' (IKAW) is available (Deeben et al. 1997). This predictive map indicates the degree to which archaeological remains are likely to be present in the soil Three different values are indicated on the map it distinguishes areas with a high, a medium ol a low likelihood of containing remains. The map was produced by means of analvsis and extrapolation ot relationships of pedological and geological teatures with the known distribution ot archaeological remains. At present, the state service is working on the development ot a second generation of this map, with additional and nuire detailed data. I he eventual result will be subjected to thorough practical testing. In collaboration with the provincial authorities, work is also being done on Integral Historical Landscape Assessment Maps' at the provincial level. The usefulness of these maps will be augmented with increasing integration ol the rlassifir allons used $\mathrm{kr}$ these maps and their inventorization methods.

Compiling inventories ol planning 01 other aieas requires research that in the Netherlands is standardized in three stages: (1) an 'initial appraisal' based on documentar research; (2) 'additional archaeological inventorv-taking', consisting ol area-oriented, usually non-destructive research in the held, and (3) 'additional 
archaeological investigation', which entails closer and usually destructive area or site investigation. In order to improve assessment in terms of intrinsic criteria, detailed insight is required into the extent and the variety of archaeological monuments, their durability and their current condition. As yet, only the first-generation predictive map (IKAW) and a provisional inventory of knowledge and knowledge lacunae are available (Groenewoudt and Lauwerier 1997) but these are far from adequate. An important tool in this respect can be the development of research frameworks such as in England (Wainwright 1991; Olivier 1996) and an agenda with clearlv defined research priorities.

In the process of selection, the determination of the level ot special relevance of a particular monument or complex of monuments to current research objectives requires detailed information about the research programmes of the archaeological heritage management agencies and the university departments. These could be brought together and published in a periodically updated 'research calendar'.

\section{CONCLUSIONS}

In a rapidly changing environment, in which archaeology is coming of age and archaeological heritage management is increasingly gaining its own place as a matter of public interest, we need to ensure that this interest is 'in .1 position to compete with other societal interests. Through the implementation of the Malta Convention or as a result of national legislation, the care for our archaeological heritage is being improved throughout Europe As a result, archaeologists are increasingly involved in decisions which may have profound legal, economic and social effects. This development has many consequences, both in the field of archaeological practice with the emergence of commercial archaeological firms. and in governmental decision-making. Archaeological interests must be wellargued, and for the public the process of decision-making should no longer be entirely a black box.

In this article, we have shown how the procedure ot valuation and selection may be carried out with clarity and - to a certain degree - objectivity. The system appears to be workable, although practical experience in the Netherlands is as yet limited and further debate at home and abroad will have to bring further refinement. It is of crucial importance that through an explicit, systematic approach to archaeologiral heritage management, excavation and other necessary investigations should continue to be relevant to academic research. However, more safeguards will be needed in this area, because the introduction ot commercial archaeology without an integral system of quality control on a statutory basis has alreadv produced a great deal of 'research' whose relevance to the creation of new knowledge about the past is, to say the least, dubious. Fortunately, many European countries are now working to improve this situation, and this will also help to narrow the gap that is sometimes experienced between academic archaeology and archaeological heritage management. 


\section{NOTES}

1. An important overview of the situation and ongoing discussion in many European countries is provided by the proceedings of the 1997 colloquium 'Archäologische Denkmalpflege Im vereinten Europa Situation - Probleme - Ziele , published in Archäologisches Nachrichtenblatt 3(2), 1998 Fo1 the Netherlands, see Willems et al. 1997.

2. These procedures were followed in the selection ot sites to be preserved in situ or to he excavated along the course ot the planned freight railway line connecting Rotterdam with the German Ruhr area.

3. In the Netherlands, aesthetic value is a legal concept, teaturing in the definition of monuments in the Dutch Monuments Act (an I nglish translation ot the Act was published as an appendix to Willems 1997).

4. This is not a very important issue in the Netherlands; in some European and in many non-European countries, however, this is the criterion which provides a basis tor taking into account the value svstems ot native populations.

5. In the dry, Pleistocene pails of the Netherlands, pool preservation tends to be the rule. To avoid the risk that in these areas $a$ quality score ot five points is never attained, a normal (i.e. poor) state of preservation will, nonetheless, in these areas score two points.

\section{REFERENCES}

Bl.Ot MI RS, T., 1997. Landschaftsarchäologie und Raumordnung in den Niederlanden. Aktuelle Trends und Themen. Archäologisches Nachrichtenblatt 2:229-243.

BRIUER I. and C MATHERS, 1996 Trendsand Patterns in Cultural Resource Significance an Historical Perspective and Annotated Bibliography. Alexandria: US Army Corps ol Engineers Virginia (IWR Report 96 EL-1).

COUNr $n$ OF EUROPE 1992. European Convention on the Protection of the Archaeological Heritage (revised). European Treaty Series, 143. Strasbourg: Council of Europe

DARVILL T., 1995. Value svstems in archaeology. In M.A. Cooper, A. Firth, J. Carman and IV Wheatley (eds), Managing Archaeology: $40 \mathrm{~W}$ London and New York: Routledge.

Darvill, T, S. Burrow and D. A. Wildgust, 1995, Planningfor the Past, Volume2. An Assessiment of Archaeological Assessments, 1982-1991, Bournemouth and London: Bournemouth University and English 1 Ieritage.

DARVILL. T. and A k .FuI ION, 1998 MARS The Monuments At Risk Survey in England, 1995. Main Report. Bournemouth and London: Bournemouth University and English 1 leritage.

DARVILL T. A. SAUNDERS and B. StaRTIN, 1987. A question of national importance: approaches to the evaluation ot ancient monuments tor the monuments protection programme in England. Antiquity 61:393-408.

I)el Ben, |, D.P Hallewas, I Kol IN and R Wiemer 1997. Bevond the crystal ball. Predictive modelling as a tool in archaeological heritage management and occupation history. In W | H. VVillems, M. Karsand D.P. Iallewas (eds). Archaeological Heritage Management in the Netherlands: 76118 Assen/Amersfoort: Van ( nri um/Rijksdienst vool het ( )udheidkundig Bodemonderzoek.

(iROI NEWOUDT, B.J., 1994. Prospectie, waardering en selectie van archeologische vindplaatsen: een beleidsgerichte verkenning van middelen en mogelijkheden Nederlandse Archeologische Rapporten, 17. Amersfoort Rijksdiensi Oudheidkundig Bodemonderzoek. 
(iROENEWOUDT, B.J. and J.H.F. Bl.oEMERS, 1997. Dealing with signifiı am C concepts, strategies and priorities for ar haeologiral heritage management in the Netherlands. In W.| H. Willems, H. Kars and D. 1'. I lallewas (eds), Archaeological Heritage Management in the Netherlands: 119-172. Assen/Amersfoort: Van (iorcum/ Rijksdienst voor het Oudheidkundig Bodemonderzoek

( ROENIWOUDT, B.J. and R.C.G.M. LAUWERIER, 1997. Kennisatlas, stand van kennis en kennisleemten; een snelle inventarisatie Interne Rapporten ROB, 33. Amersfoort: Rijksdienst voor het Oudheidkundig Bodemonderzoek

LEONE, M I' and I' H . POTTT K JR., 1992. Legitimation and the classification of archaeological sites. American Antiquity 57:137-145.

L.IPE. W. D.. 1984 Value and meaning in cultural resources In II (leere (ed.) Approas hes to the archaeological heritage $1 \mathrm{M}<$ ambridge Cambridge University Press

LUNING, J., 1997. Landschaftsarchäologie in I leutschland, em Programm. Archäologisches Nachrichtenblatt 2:277-285.

MACINNES, L. and C.R. WickHAM-Jones, 1992 AH Natural Things. Archaeology and the Green Debate Oxbow Monograph, 21 . Oxford: ( )xbow.

MORATTO, M.J. and R.E. KIIIY, 1978 Optimizing strategies fol evaluating archaeological significance Advances in Archaeological Methodand Theory 1 i in,

NeustuPny, E., 1991 Community areas of prehistori tarmers in Bohemia Antiquity 65:332-347.

OLIVIER, A., 1996 I rameworks for our Past. A Review of Research Frameworks, Strategies and Perceptions. London: English Heritage.

REED, $A D, 1987$ A technique for ranking prehistoric sites $m$ terms ol scientific signific anc e American Archaeology 6:127 130.

ROORDA, I.M and R. WIEMIR, 1992a. The Archis Project towards a new national archaeological record for the Netherlands. In ( IJ . Larsen (ed.), Sites and Monuments National Archaeological Records 117-122. Kabenhavn: National Museum ol Denmark.

RooRDA, L., and R. WIEMER, 1992b Towards a new ar haeological intormation system in the Netherlands. In G. Lock and ]. Moffets (eds), Computer Applications and Quantitative Methods in Archaeology (BAR International Series 577): 8,s 88. (Mord:BAR.

SCHUYF, ), 1995. Heidens Nederland: Zichtbare overblijfselen van een niet-christelijk verleden. Utrecht: Matrijs.

Startin, B., 1993. Assessment ol held remains. In ]. I funter and I. Ralston (eds), Archaeological Resource Management in the UK, an Introduction 184 196. Stroud: Alan Sutton.

WaINWRIGHT, G.J., 1991. Exploring our Past, Strategies fur the Archaeology of I ngland. London: English I Jeritage.

Willems, W.J.H., 1997. Archaeological heritage management in the Netherlands: past, present and future. In W.J.H. Willems, II Kars and D.P. I lallewas (eds), Archaeological Heritage Management in the Netherlands: 3-34. Assen/Amersfoort: Van Gorcum/Rijksdiensı voor het Oudheidkundig Bodemonderzoek

Willems, W.J.H., H. KARS and D.P HaLLFwAS (eds), 1997 Archaeological Heritage Management $m$ the Netherlands. Assen/Ameistoorl: Van 1 irorcum/Rijksdienst voor het Oudheidkundig Bodemonderzoek.

ZOETBROOD, P.A.M., M.J.G. MONTFORTS, IM ROORDA and K. WIEMER, 1997. Documenting the archaeological heritage In W. J.H Willems, H. Kars and DI' I lallewas (eds), Archaeological Heritage Management $\boldsymbol{m}$ the Netherlands 330-345. Assen Amersfoort Van Gorcum/Rijksdiensł voor het Oudheidkundig Bodemonderzoek. 


\section{APPENDIX: PARAMETERS}

This appendix presents an overview ot parameters that may be used in attaching si ores to the various criteria Extensive practical expenence has been gained already with the criteria relating to the physical condition ot" monuments. The others are still at an experimental stage.

Aesthetic value

- Visibility from the surtace as a distinctive landmark

- Shape and textute

- Relation to the surroundings

I Iistorical value

- Links with factual historical events

- Ascribed qualities or significance

\section{Integrity}

- Presence ol teatures

- Integrity of teatures

- Spatial integrity

- Intact stratigraphy

- Movable finds in situ

- Spatial relations among movable finds

- Spatial relations between movable finds and features

- Survival ot anthropogenic biochemical residues

\section{Preservation}

- Preservation ot artetacts (metal/other)

- Preservation of organic material

\section{Ra1 ity}

- The number of comparable coeval monuments ot good physical quality within the same archaeo region whose presence has been demonstrated

- The same, expected on the basis of a recent and specitir predictive map

\section{Research potential}

- Full or partial exr avation/investigation of comparable monuments within the same archaen region (mine/less than $\mathrm{S}$ vears ago)

- Recent and systematic study ot the aichaeo region concerned

- Recent and svstematic investigation of the archaeological period concerned

- Relevance to a pre existing research programme of a universits department or government agency 
Group value

- Synchronie context (presence of coeval monuments within the same microregion)

- Diachronie context (presence of monuments of various perii $>$ ds within same the micro-region)

- Geographical context (physical and historical-geographical integrity of the landscape)

- Presence of organic sediments in the dose vicinity

\section{Representativity}

- Number of comparable, coeval monuments of good physical quality within the same archaeo-region, whose presence has been demonstrated

- The same, expected on the basis of a recent and specific predictive map

- Typicality in an international perspective

- Conformity with the policy of the government concerned

\section{BIOGRAPHICAL NOTES}

Jos Deeben is a researcher in the Department of Research and Development of the Dutch State Archaeological Service (ROB). He has published on Late Palaeolithic and Mesolithic settlement systems and, together with Daan P. Hallewas, he is currently responsible for the development of the 'Indicative Map of Archaeological Values of the Netherlands'.

Address: ROB, PO Box 1600, 3800 BP Amersfoort, The Netherlands. [email: jdeeb@archis.nl]

Bert J. Groenewoudt is a senior researcher in the Department of Research and Development, ROB. In 1994 he received his $\mathrm{PhD}$ at the University of Amsterdam on a thesis about the survey, valuation and selection of archaeological sites and he has published various articles on this subject as well as on settlement research in the eastern Netherlands.

Address: ROB, PO Box 1600, 3800 BP Amersfoort, The Netherlands. |email: bgroe@archis.nl] 
Daan P. Hallewas is ,1 senior researcher in the Department of Research and Development, ROB. He has published, inter alia, on archaeological cartography and palaeo geographical reconstructions. He is currentlv responsible with los Deeben lot the development of the 'Indicative Map of Archaeological Values of the Netherlands'.

Address: ROB, I'O Box 1600, 3800 BP Amersfoort, the Nethellands.

Willem J.H. Willems is Director tor Archaeological Heritage Management at the Ministry of Education. Culture and Science and Professol of Roman Archaeology at the University of Leiden I le is the former Director ot the ROB and his resear $h$ his centred on Roman provincial archaeology and on various aspects of heritage management. Currently, he is the President of the EAA.

Address: Ministerie van OCW, PO Box 25000, 2700 LZ Zoetermeer, The Netherlands. [email: w.will@consunet.nl]

\section{ABSTRACTS}

Propositions pour un système pratique d'évaluation de la-signification dans la gestion du patrimoine archéologique

Ios Deeben, Beri I Groenewoudt Daan P. Hallewas et Willem \} H Willems

Dans 1,1 gestion du patrimóne ari héologique I'évaluation de 1,1 signitivation joue un rồle central. Dans cel article, une approche pratique esi ofterte, fondée su des exper ienues cl des discussions rérentes au Pavs Bas I In certain nombre de données (perception qualitê physique cl qualité intrinsique) soul utilisées en tant que critères d'êvaluation du phénomène archéologique De cette taçon. un système de réference plus , laiı esı crée pou aideı determineı si un monument vauı la peine d'elle préservé. Durant le processus de selection, les monuments sont eximinés en fonction des < onsidéritions et des priorités qư régissent la gestion du patrimoine archéologique atin de dérider le type de monuments qui benefirieront d une préservation plus poussée $\mathrm{I}$ a forme de ce svstème d'évaluation esi telle qu'il peut être utilise , 1 tous les niveaux de gouvernement qu il esi comprehensible pom les non archéologues et produit des resultats toujours pertinents du point de vue de la reiheri lle.

\section{Vorschläge für ein praktisches System von Signifikanz-Bewertung in der Verwaltung archäologischer Denkmäler}

\section{Jos Deeben, Bert l Groenewoudt Daan I' Hallewas und WillemI.H. Willems}

In deı an häologischen I lenkmalpflegespiell die Bewertung del Signifikants archäologischer Phänomene eine zentrale Rolle. In diesem Artikel soll ein praktis hes Beispiel vorgestell weiden, welches aus den in den Niederlanden gemi hten I rfahrungen entwickell würde I inige Werte (I rlebung, physische Qualität und inhaltliche Qualität) wurden als Kriterien zu Bewertung an häologischer Phänomene nutzbas gemarht Aul diese Weise konnte ein klares Verfahren entwickelt weiden. weli hes bestimmen hilft, oh ein Denkmal Erhaltungswerl hat Im Zuge dieses Auswahlprozesses weiden erhaltungswerte Denkmäleı aus politischer Sicht und hinsichtlich der Prioritäten der au häologischen I enkmalpflege geprüt um dann entscheiden zu können, tüı welche Denkmäler eine dauer halte Erhaltung anzustreben ist.

I lieses Auswertungssystem fü die Bedeutung del Signifikants isı derarl gestaltet daß es aut jede V'erwaltungsebene anwendba1 ist, daß del Prozess ebenso nicht Archäologen verständlich ist und die Resultate dabei ihre wissenschaftliche Relevanz behalten. 